Historic, Archive Document

Do not assume content reflects current scientific knowledge, policies, or practices. 


\section{Kansas Home Nursery and Experimental Grounds.}

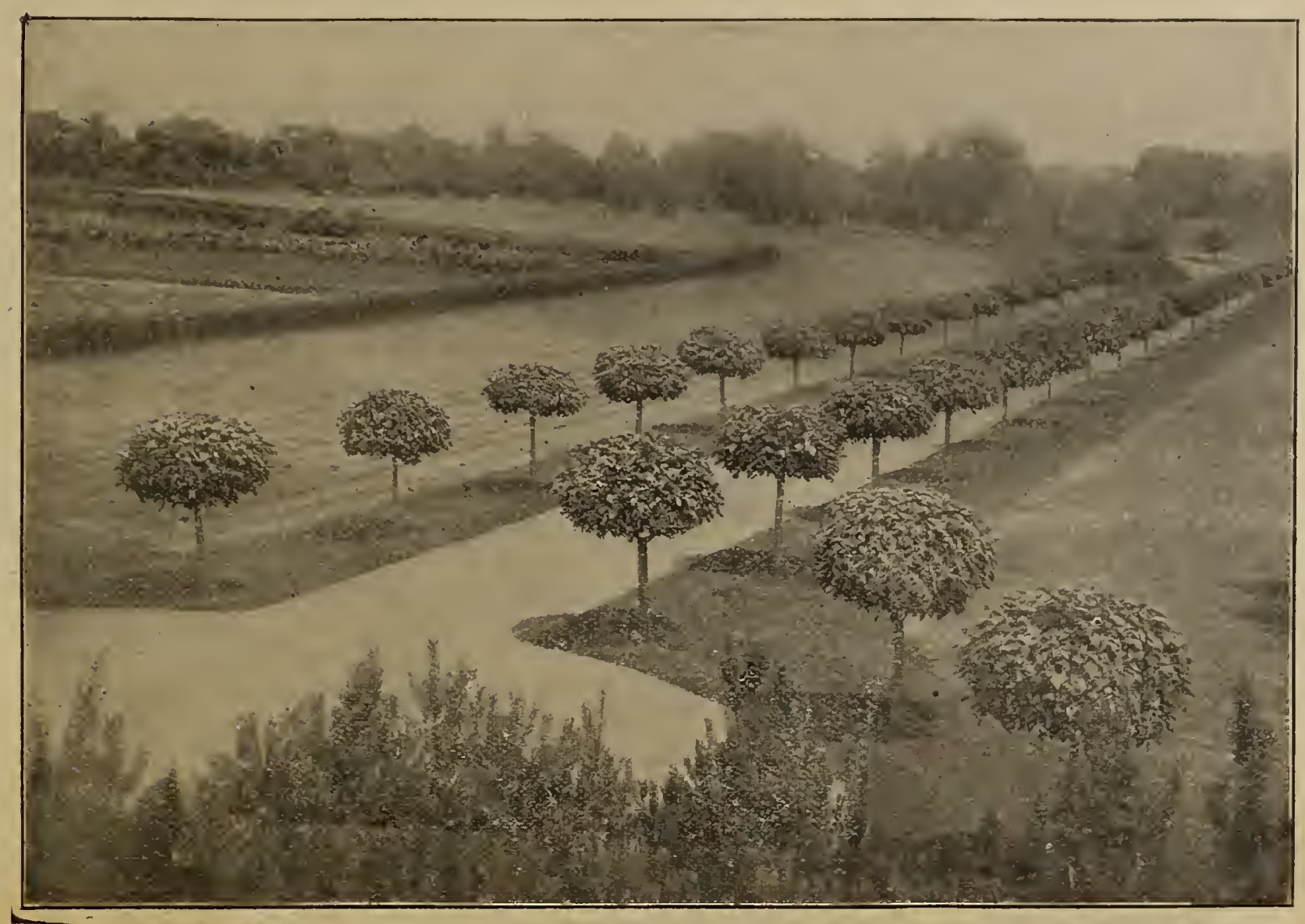

Nothing "sells itself"; yet there are trees and plants so/in leaf or not. It is perfectly hardy and thrives in any soil commonly known as to require no description or picture to As yet they are little known, but when once they are seen introduce thent. On the other hand there are a great many beautiful and desirable varieties which are almost unknown except to large parks and arboretıms. Many of these are scarce and high, are hard to propagate but easy to grow when once obtained. The object of this bulletin is to call attention to some of those most desirable and adapted to your climate. We grow nothing whatever except that which is perfectly liardy.

We wisl you to study and push especially those that are starred "*”, which a re OLR SPECIALTIES.

* Catalpa Bungei (Umbrella Catalpa) is a tree of special merit,as it requires no pruning to shape its beantiful canopy of larye bright green leares,(brighter than most other trees) which stayion late in antumn. It is a strong vigorous grower perfectly hardy and free from insect or disease; resists dronth and will $\mathrm{grow}$ in the poorest soil. Nost easy to transplant and in time will spread a top of 20 to 30 feet in dianeter. (See above cut of Catalpa Bungei driveway.)

* Ceciduous Cypress. Native of a moist region, yet it thrives on the dry ridgeland at the Agricultural College, lanhattan, Kansas, where it has grown for over 30 years and never suffered from cold or drouth ; thus showing the great adaptability of the tree. It grows here on "hard-pan" or "gumbo," subsoil as well as on sand. It makes a symmetrical tree, tall and straight as an arrow, with graceful pendant branches and soft green foliage, resembling the native Larch.

growing the demand will be great.

*The Un-Named Perpetual. Is a variety unlike most others in that it make a large, quick-growing tree, entirely hardy, with beautiful foliage, abundance of flowers from spring to fall. It is a rapid grower, making an erect, dark red trunk from which are its abundant branches and rich foliage, soft and feathery with pink flowers, makes it a tree remarkable as it now is rare. We know one of this kind with a diameter of trunk of 15 inches, and a young tree yet.

*The Silver ramarix, Amurensis, is a native of the Amoor river, boundary between China and Siberia, and is perfectly hardy in Iowa. This variety has beautiful silvery foliage, and is better grown as a dwarf tree or shrub, and as such it can bekept to any size desired. Nothing so beautiful planted as a screen, whether in bloom or not. We hare. many other varieties imported from all parts of the world one a weeping variety not yet for sale.

*Koel Reu Teria or "Golden Rod Tree." The Japan Koelreuteria is one of the most beatiful of our small trees having striking characteristics all the seasons. When in springtime of its growth, few fern fronds are prettier than the leares of this tree. At midsummer its krilkiant golden flowers make it a complete mass of beanty, while in fall its rich crimson vies with many of our American trees that have been celebrated in this respect. Eren in winter the characteristic growth of the branches is particularly striking (Neehan.) Its great compound leaves resemble

*The Tamarix, (not Tamarack.) This class of shrubs fern fronds and foilowing the large panicles of blossoms or trees (as grown) has fine and delicate foliage, resembling are clusters of puff balls, changing from light green to dark Juniper, but soft and graceful, and of various shades of brown. A little grirl spoke of it as the "Golden Rod Tree," green, and bearing pink flowers; always, beatiful whether and not without good reason. Anyone planting this tree 
will have something rare and always beautiful.

*The Russian Olive. Is a hardy tree with clean, dark brown limbs, shining as if varnished and becoming nearly black when large, the small twigs and the leaves being silvery white. Remember that the leavesare silvery white and remain so throughout the season. In May and June it is covered with little racemes of blossoms, starting from the axtil of each leaf, each blossom as large as the end of a pencil, yellow with black throat. These are very pretty for bouquets and have a sweet, spicy odor, not strong,yet it carries with the wind forty rods. Each bud is double and it produces blossoms on one, two and three-year-old wood, thus furnishing a great amount of bloom during the season.

The contrasting colors of bark, twigs, leaves and flowers; and its graceful growth, make it a most beautiful sight. This tree is very hardy, withstanding the extreme dronth of the Southwest and the cold of the Dakotas; thrives in the dry regions of western Kansas, Neb., Colo. and Oklahoma. A single flowering branch placed in a vase is a most beauti. ful boquet in itself. We consider it one of the most valuable of new trees, yet it has been long tested, as it was introduced into this country by the Mennonites who kept it to themselves; but now trees are found growing 40 feet high from their planting.

*The Pergimmon. The native Persimmon is a handsome and hardy tree, entirely free from insects. Its fruit is relished after a sharp frost has removed the "pucker" and finds a ready market in the east. We have now succeeded in obtaining varieties which are two to three times as large, and which mature their delicions fruit before frost, retaining none of the astringency of the native varieties; Among others the American Honey, Golden Gem, Johnson, Hicks and the Seedless, are the best. The fruit of these is about the size of a small tomato with flavor of fruit and honey. The tree has large glossy green leaves, and will bear at four years old and continuously thereafter. Beware of seedling trees which never fruit, but ours are all propogated from bearing trees.

* Japan Walnut. Is a new addition to our food-bearing trees which will please everyone for ornament or for nuts. It is a quick growing, sllooth, white barked tree; perfectly hardy-coning through the winter of 99 , and fruiting at four years old. Its nuts are borne in clusters of 15 or 20 , and so soft shelled as to be readily cracked by the teeth, and have a flavor superior to the butternut. Everyone should try these, for besides being a handsome shade tree with inmense leaves, the nuts can be sold at good figures.

Prunus Pissardiii. Pissard's purple leaved plu11. It is from Persia, and its bright orange and purple colors are splendid for a background to some lighter tree or shrub.

Double Flowering Peach, And Alunond we have in five colors, with flowers two inches across.

Scarlet Flowering Apple. (Pyrus Parkmanni.)

\section{Weeping Apple. (Silver Leaved.)}

Bechtel's Double Flowering Crab. All are fine for the yard.

Tulip Tree. And all Magnolias are well worth their cost and the extra care needed to get them established. The Chinese varieties bloom before the leaves appear. The Tripetala has large white flowers in May. The Macrophylla has leaves two feet long and flowers in June over a foot across, followed by carmine seed pods. They succeed best if noved in spring.

Am. Sweet Chestnuts. Many people from the East long for those good old days when they used to go chestnutting -never supposing that they conld raise them in the West; but we find them one of the easiest and hardiest of trees and have specimens a foot in diameter, on onr experimental grounds, which bear abundantly every year.
Carolina Poplar. Is one of the most desirable quick growing trees for the Southwest as it gives a comforting shade quicker than any other tree, and its top can be easily pruned to give the desired shape; its large green leaves soon furnish a pleasing retreat from the hot sun. It is never troubled with dronth or with insect pests, and seems to thrive in any soil.

Weir's Cut--Loaved Maple. Is another fast growing tree with drooping branches and fine cut-leaves-an intprovement on the old Silver Maple.

* Meeping Russian Mulberry. Will never disappoint for a yard or cemetery tree, and if cut back each winter, it will weep to the ground the following summer.

Wisconsin Weoping Willow. Being a natural weeper can not be spoiled by "loosing its head" and the older it gets the more beautiful the effect. The Thurlow is said to be an improvement. The Diamond Willow is said to be nearly equal to the Cedar for posts.

Mulberries. A re not planted as much as they should be. The Russian is a valuable timber tree, and worth growing for the birds and boys alone. The Downing bears fruit as large as a blackberry and as lucious. Its fruiting period extends from June to September, and the Kansas Everbearing is full of fruit from June to frost.

Dwarf Juneberry. Speak of Huckleberries or Blueberries and any native of the north will smack their lips; and yet few know that in the Divarf Juneberry we have a hardy fruit of the same family, with the same sweetness and flavor, very productive and requiring no care to speak of. It bears at two years old and never fails thereafter to produce an immense crop of its lucions fruits, and 12 plants will supply a family.

*Push the Cardinal Raspberry, the great money maker for the Southwest. The only red berry which succeeds in that section. Largest yield of fruit witl small cost of production. Every family should have from 12 to 100 plants.

Among the shrubs we can not too highly recommend are the New Lilacs. The Tree Lilac blooms four weeks after the common ones, great panicles of creamy white.

Forsythia-Golden Bells. Its saw-toothed leaves are handsome all summer, and its flowers, which are produced in early spring, earliest of all, a re yellow and rope the limbs from end to end.

Weigela-Old Favorite. Large, trumpet shape pink and white flowers. The Variegated is very fine, with its yellow and pink-edged leaves.

Pugple Fringe-"Smoke Tree," "Fire Bush," "Mist Tree," etc., makes a large shrub or tree.

Spirea Of these we can furnish a siccession of flowers from May to October. In addition to the white, shrubby varieties, such as "Bridal Wreath," we have the Anthony Waterer, a dwarf plant, with ornanental foliage, covered all snmmer with clnsters of crimson flowers, very handsome, and you can push this new plant.

* àolden Elder. Leaves bright yellow, flowers white, they enliven a yard-in contrast with the darker-leaved plants. Ii e havealso a Cut-leaved Golden and a Silver-maroined Elder. They will sell and please.

Syringa. The sweet-flowered Mock Orange, everyone wants it if they hav'nt it. We have also the Grandiflora with flowers as large as a silver dollar.

Moss Locust, or Rose Acacia, is a fine old shrub with larce clnsters of rosy pink, sweet-pea-like flowers, stem and branches covered with red, mossy growth like the moss rose.

The Althea, a handsome slirilh, 3 to 10 feet high, does not spread, bloom first year from July to frost, flowers are donble 
three inches across; 12 varieties, all colors; also the Variegated-leaved, foliage variegated with light yellow. All very fine.

Calycanthus, or Sweet Shrub, is all old favorite; Howers and leaves are highly fragrant: sweet spicy odor.

Deutzia, blooms profusely in June; clusters of double white flowers as larue as a nickel.

Hydrangea, laniculata Grandiflora. Flower on new wood the first year and if cut to the gromel they will bloon just the same, from July to October; immense trusses a foot across; white, changing to pink. Can be grown tree or bush form, as desired.

Upright or Tartarian Honeysuckle. grows to a handsome tree or bush, and its flowers ale very sweet; early; two varieties, pink and white.

California Privet. makes a very dense, green hedge, but thornless; can be pruned in any desired shape; very fine for dividing walks or lots, in place of the unsightly fences.

Quince. Japan Rose-flowering; brilliant scarlet flowers in spring; also useful for hedge or screen.

* New Japenese Trailing or Memorial Roses. Have but to become known to be appreciated. The Wichuriana is the original Japanese form, having fine glossy foilage and white flowers and is especially desirable as a cemetery plant or for covering mound, rockery or trellis; makes a good growth the first year; the flowers are produced in clusters on the end of every branch, after the June roses are past; they are pure white with yellow stamens; strongly fragrant like the Banksia rose.

*The Hybrids. Are similar in habit but the leaves vary in slape; will cover a large surface with dense growth in a single summer. The foliage retaining its beauty through January. We have then in all shades of pink, cream, yellow find white. Solle very doubie and 2 to 3 inches across. Our pictures do wot do them justice, but you can recommend thell highly.

In Hybrid Perpetual Roses we have the very finest, of all colors. In1 press that the varieties are not the common ones that sucker over the garden, but the very best. new, delicately colored roses that can be obtained and not "rooted cuttings," sich as a re sold by florists, but strong field-grown plants which will bloom the first season, and the entire season from June to frost, if treated according to our directions. The Standard Tree Roses are all imported and worth price asked. (\$2.50.)

VINES-For covering mound, screen or wall, nothing is more liardy and satisfactory than the American IVy (Va. Creeper or Honeysuckle-these we have in scarlet, yellow pink and white and Hall's Japan sweet scented.

The Boston Ivy. (Japanese A. Veitchii.) Has very fine leaves, grows rapidly and clings to brick or stone. Nothing could be finer tlian its gold, scarlet and crintson autumn shades.

Clematis. (Large flowering.) We have in all shades of red white and blue, and the Clematis Paniculata, a novelty from Japan. It has proved to be one of the most desirable and beatiful of hardy climbing vines. It will soon cover any support given it; its flowers of medium size, pure white, resembling the orange, very fragrant and produced in greatest profusion in late summer. It makes growth of 25 to 30 feet in a season and can be cut back to the $@$ round each spring.

Don't forget the Matrimony Vine, Wistaria, Amer. ican Chinese Purple and White, Trumpet Creeper, Bitter Sweet (Celastrus.)

IV henever you see a chance for a climbing vine, sell a Clematis-eitler the Paniculata white, or some of the large flowerino varieties; or Honeysuckle, Wistaria, Aupelopsis or climbing rose.
Give more attention to the Iferbaceons Plants, which re. yuire 110 care exeept to ke(p) down the weeds. They send ilp a llew growth every yeir, are perfectly harly, bloom profusely, and with a selection can be land in flower from carly to late. Six varieties for $\$ 2.00$.

Erianthus-Ilardy l'ampas Grass.

Careopsis-Golden ll'ave.

Hemerocallis Lemon Lily.

Golden Glow Will bear hundreds of beautiful clear yel. low flowers. Adnired by everyone.

Hardy Hibiscıls with grreat flowers as la roe as ál sancer.

Plumbago-Deep blue all summer and fall. Fine for edging.

Japan Lilies-Perfectly hardy. Plant in fall only

Dahlias-Plant in spring only. Winter like potatoes.

Always reliable for flowers from the middle of sunimer un til fall. All colors-yellow, white, pink and shades.

Peonias-In great variety. The Yuccas are fine for city planting; because they stand dry and poor soil and in any position; flowering spikes rise 6 feet high, covered with hundreds of creamy white flowers the size of a half dollar.

\section{HEDGE PLANTS FOR THE WEST AND SOULHWEST.}

The Arboraitae $\uparrow$ - Is the best of the evergreens, and should be planted 18 to 24 to the rod. according to the size-the 12 to 18 inch size is the best.

California Privet-Is the most highly prized of all the thornless hedge plants. It wakes a dense growth of stenı ; non-suckering, with glossy green leathery leaues which are nearly evergreen. It can be easily shaped to any forni or height, from one foot to six. If it is double rowed like this:

from 8 to 16 inches apart, it will make a solid stock-proof fence-useful as well as ornamental. There is nothing finer for dividing lots or for a thick screen, and but little work is required to keep it in condition. Its flowers resemble the white lilac.

The Althea - With its large Hollyhock-like flowers, constant from Angust to frost: and tle Silver Tamarix门 for a purely ornamental hedge or screen-cannot be surpassed.

Japan Quince-Is thorny enough to turn stock, easily pruned to desired heighth and will not spread or overgrow its place and usefulness, as does the Osage. The pruning will always be light, and as it makes a thick shining hedge when in leaf, and a beautiful bouquet of scarlet flowers very early in the spring, covering every branch and twig before the leaves are developed; it seems that this combination of the useful with the ornamental would soon be rery popular if they could be obtained as cheaply as the Osage. For defense it should be double-rowed and planted one foot, more or less, according to the time you wish to wait for a thick hedge.

The Barberry-Is very little known, yet one of the hardiest, healthiest, cleanest and closest plants for hedge Never too large, and as it never suckers, but stools only so that it will soon become impossible to force your way through a mass of its hundreds of straight stems (gracefully curving orer at the top) even were it without those short, sharp thorns. It has handsome leaves and every year it will be covered with rellow flowers in drooping racemes, in May, followed by scarlet fruit which hangs on all winter. The wonderful part is that this fruit-between a Currant and a 
Cranberry in size and flavor-does not get quite ripe until after frcezing weather and can be picked and used at any time during the winter; each frost only making it milder but not injuring its flavor in the least; and it can be kept in the snow like the Cranberry. It is acid enough to make the finest jelly, pie or preserves and is highly esteemed by those who have used it. When you take this into account and that it will make you a permanent fence hedge (the writer knows of one standing now more than 26 ycars, without any carc, and the ncighbors helping themselves each winter to the fruit) what more can you desire to start in " a treeless country? It is cheap, it is easy to grow, it will pay to plant even if you have to put a temporary fence onc sicle of it until it gets strong. It would never grow more than 8 feet high but spends its time in sending up new shoots to thicken itsclf much as does a grass sod. Plant one foot apart or double row for stock hedgc.

The Purple-Leaved variety costs a little more but is more ornamental for about the home. Barbery Thunbergit is a natural dwarf variety, growing not over two feet, with very small leaves, getting a coppery-red color in winter, sharp thorns, good fruit, very desirable for any yard where a division is required, but more for ornament than for protection.

All of the above mentioned plants (except those $\dagger$ ) will make permanent, stock-proof, pretty, profitable, and in the long run, the cheapest fence. When once they are understood they will supercede the old "hedge" and Locust, as the wire did the rail fence. None of of those mentioned require pruning, but all are better for it, and if desired can be kept in any shape-roof, round or square top-and this can be done easily with hand shear and at small cost compared to that required for Osage, and in ten years will have saved their extra cost in the work, to say nothing about the "thing of beauty which is a joy forever."

For city planting these take the place of all fences and division lines, turning ugliness into beauty. $A$ fence in bloom is no weariness to the eyc.

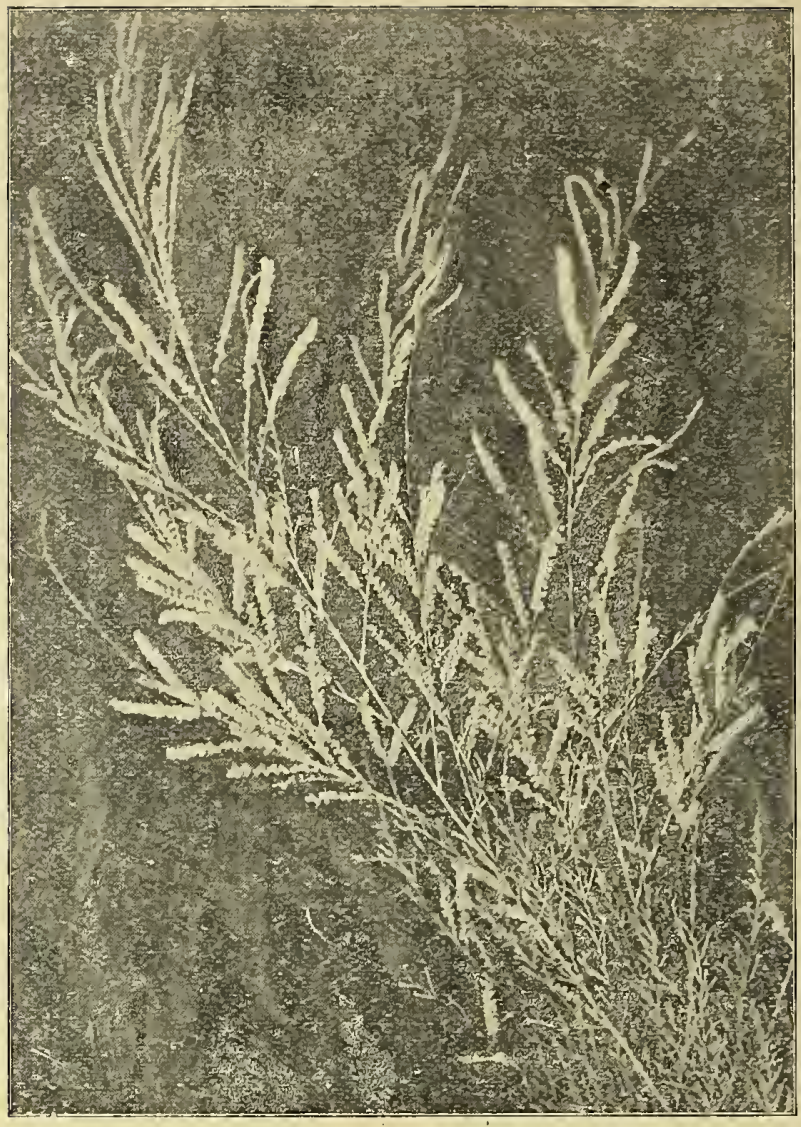

TAMARIX.

Remember that every tree or plant adcled to any place will enhance the value of that place as a home or should it be for sale.

Remember that these ornamentals will be in immediate effect the first year. We have been growing stoek here in Kansas since 1867 and our many acre in experimental grounds arc open to you at all times, and we invite vour PERSONAL INSPECTION.

Freight paid on retail orders of $\$ 10$ and $u p$.

KANSAS HOME NURSERY, Lawrence, Kansas.

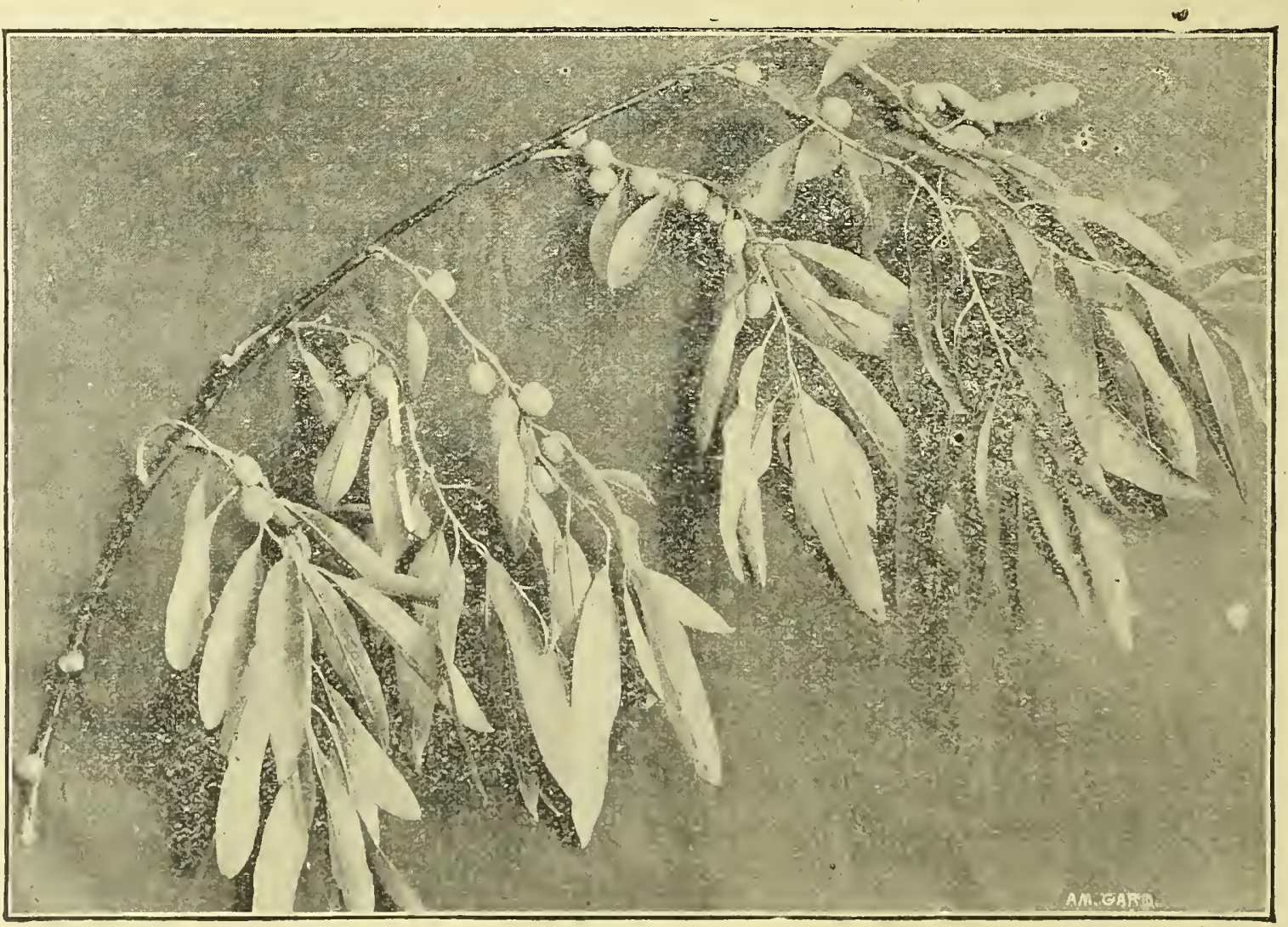

RUSSIAN OLIVE. 